Article

\title{
Synthesis and Structure of the Inclusion Complex $\left\{\mathrm{NdQ}[5] \mathrm{K} @ Q[10]\left(\mathrm{H}_{2} \mathrm{O}\right)_{4}\right\} \cdot 4 \mathrm{NO}_{3} \cdot \mathbf{2 0 \mathrm { H } _ { 2 } \mathrm { O }}$
}

\author{
Li Xia Chen ${ }^{1}$, Jing Lan Kan ${ }^{2}$, Hang Cong ${ }^{1}$, Timothy J. Prior ${ }^{3}$ (D), Zhu Tao ${ }^{1}$, Xin Xiao ${ }^{1, *}$ and \\ Carl Redshaw ${ }^{3, *}$ (i)
}

1 Key Laboratory of Macrocyclic and Supramolecular Chemistry of Guizhou Province, Guizhou University, Guiyang 550025, China; chenlixia19@163.com (L.X.C.); ecnuc@163.com (H.C.); gzutao@263.net (Z.T.)

2 College of Chemistry, Chemical Engineering and Materials Science, Collaborative Innovation Center of Functionalized Probes for Chemical Imaging in Universities of Shandong, Key Laboratory of Molecular and Nano Probes, Ministry of Education, Shandong Normal University, Jinan 250014, China; kanjinglan@163.com

3 Department of Chemistry, School of Mathematics and Physical Sciences, University of Hull, Hull HU6 7RX, UK; t.prior@hull.ac.uk

* Correspondence: gyhxxiaoxin@163.com (X.X.); c.redshaw@hull.ac.uk (C.R.); Tel.: +86-851-8362-0906 (X.X.); Fax: +86-851-8362-0906 (X.X.); +44-148-246-5219 (C.R.)

Received: 23 June 2017; Accepted: 6 July 2017; Published: 9 July 2017

Abstract: Heating a mixture of $\mathrm{Nd}\left(\mathrm{NO}_{3}\right)_{3} \cdot 6 \mathrm{H}_{2} \mathrm{O}, \mathrm{KCl}, \mathrm{Q}[10]$ and $\mathrm{Q}[5]$ in $\mathrm{HCl}$ for 10 min affords the inclusion complex $\left\{\mathrm{NdQ}[5] \mathrm{K} @ \mathrm{Q}[10]\left(\mathrm{H}_{2} \mathrm{O}\right)_{4}\right\} \cdot 4 \mathrm{NO}_{3} \cdot 20 \mathrm{H}_{2} \mathrm{O}$. The structure of the inclusion complex has been investigated by single crystal X-ray diffraction and by X-ray Photoelectron spectroscopy (XPS).

Keywords: inclusion complex; cucurbit[10]uril; cucurbit[5]uril; neodymium; potassium; structure

\section{Introduction}

Cucurbit[ $n$ ]urils have attracted increased attention over the last decade or so, with much of the interest resulting from their recognition properties [1]. Their varied chemistry and structures together with potential applications have been discussed in a number of recent reviews. We and others have been interested in their host-guest chemistry, as well as the application of their recognition properties [2-6]. We have also been attracted by a number of reports in which a smaller member of the $\mathrm{Q}[n]$ family can be trapped in the cavity of a larger member of the series. Such inclusion complexes for Q[5] and Q[10] were first reported by Day and coworkers [7]. In particular, the gyroscane (gyroscope-like) species [Cl@Q[5]. $\left.\left(\mathrm{OH}_{2}\right)_{2}\right] @ \mathrm{Q}[10]$ was structurally characterized and could be isolated on $65 \mathrm{~g}$ scale. Later studies showed it was possible to isolate free Q[10] from this inclusion complex [8]. More recently, Liu et al. employed a template route to access the inclusion complex [ $\left.\mathrm{H}_{2} \mathrm{O} @ \mathrm{Q}[5] \mathrm{K}_{2} @ \mathrm{Q}[10]\right] \mathrm{Cl}_{2}(\mathrm{HCl})\left(\mathrm{H}_{2} \mathrm{O}\right)_{37}$ [9]. We were intrigued by the stabilizing ability of the potassium ions in this structure and have embarked upon a programme to investigate other cucurbit $[n]$ uril inclusion complexes, particularly species in which smaller $\mathrm{Q}[n]$ reside within much larger $\mathrm{Q}[n] \mathrm{s}$.

\section{Results and Discussion}

A mixture containing Q[6], Q[8] and Q[5]@Q[10] was generated by heating glycoluril, paraformaldehyde and hydrochloric acid at $100{ }^{\circ} \mathrm{C}$ for $6 \mathrm{~h}[10,11]$. Subsequent treatment with $\mathrm{HCl}$ and amantadine resulted in isolation of amantadines-Q[10], from which pure $\mathrm{Q}[10]$ can be obtained on work-up using DMSO [12]. An equimolar mixture of Q[10] and Q[5] was dissolved in $\mathrm{HCl}(1 \mathrm{M})$, to which neodynium nitrate and potassium chloride were added. Following brief $(10 \mathrm{~min})$ heating $\left(80^{\circ} \mathrm{C}\right)$, the solution was left to stand at ambient temperature under air. On prolonged standing (5 weeks), 
single crystals suitable for X-ray diffraction were obtained in about $12 \%$ yield. The molecular structure is shown in Figure 1, and it can be seen that as for the structure reported by Liu et al. [9], the Q[5] is contained within the Q[10]. Here however, as well as being locked in place by a $\mathrm{K}^{+}$ion, the rigidity of the structure (versus gyroscane) is enhanced by coordination of $\mathrm{Nd}\left(\mathrm{H}_{2} \mathrm{O}\right)_{4}{ }^{3+}$. Furthermore, between the $\mathrm{Q}[n]$ s there are four nitrate ions and approximately 20 additional unbound water molecules present (some of which are identified by the PLATON Squeeze routine). The Q[5] is not co-planar with the $\mathrm{Q}[10]$. Although their centroids are very close $(\sim 0.167 \AA$ apart $)$, the $\mathrm{Q}[5]$ is rotated so that the plane of this molecule is inclined at $62^{\circ}$ to the plane of the Q[10].

The view of the inclusion complex given in Figure S1 (see ESI) emphasizes how the neodymium centre sits above the central mean plane ('belt') of the Q[10] by approximately 1.63(2) $\AA$. This neodymium centre is disordered over two positions Nd1 (56.33(18)\% occupied) and Nd2 (43.67(18)\% occupied). By contrast, the potassium ion is embedded in the structure. The coordination geometries about each $\mathrm{Nd}$ centre and $\mathrm{K}(1)$ are illustrated in Figure 2. The five shorter $\mathrm{K}-\mathrm{O}$ bonds $(<2.9 \AA)$ are to the $\mathrm{Q}[5]$, whilst the other two longer $\mathrm{K}-\mathrm{O}$ bonds (>3.1 $\AA$ ) are to the Q[10]; for the Liu structure, the K-O bonds to the Q[5] are <ca. 2.9 $\AA$ and the longer bonds to Q[10] > 2.9 $\AA$ [9]. For each of the two 7-coordinate $\mathrm{Nd}$ positions, the bond lengths to the $\mathrm{Q}[n] \mathrm{s}$ and those between $\mathrm{Nd}$ and $\mathrm{H}_{2} \mathrm{O}$ are similar at ca. 2.4 to $2.5 \AA$. Dimensions across the Q[10] (for carbonyls across the length of the Q[10]) are in the range 11.39(2)-13.82(2) $\AA$ (see Figure S2, ESI); for the Liu structure, the range is 11.9-13.7 $\AA$ [9].

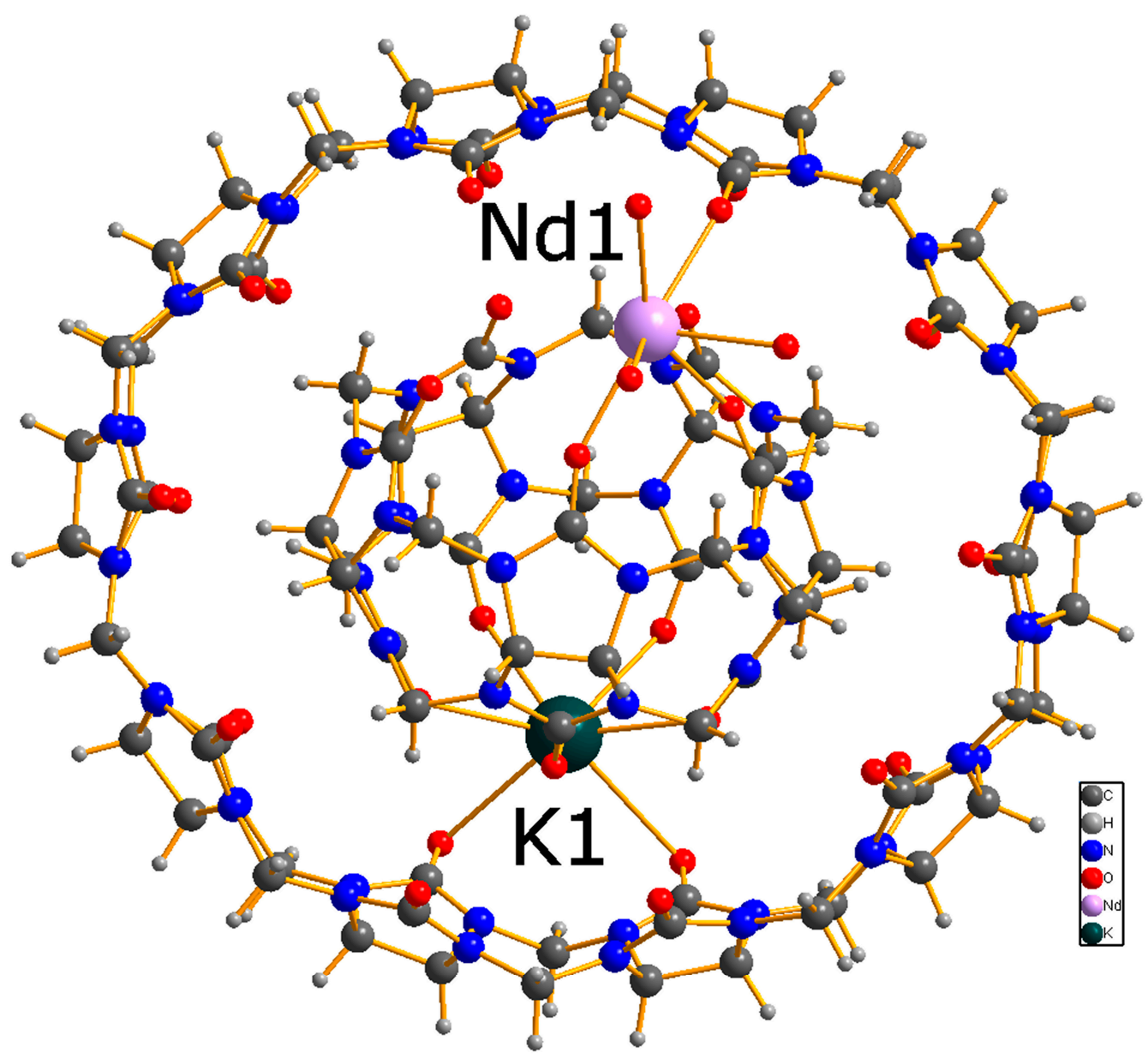

Figure 1. Molecular structure of the inclusion complex $\left\{\mathrm{NdQ}[5] \mathrm{K} @ Q[10]\left(\mathrm{H}_{2} \mathrm{O}\right)_{4}\right\} \cdot 4 \mathrm{NO}_{3} \cdot 20 \mathrm{H}_{2} \mathrm{O}$ as viewed from the top. 



Figure 2. Coordination environments around $\mathrm{Nd}(1), \mathrm{Nd}(2)$ and $\mathrm{K}(1)$.

We note that in the literature a number of $\mathrm{Nd}$ complexes have been previously reported for $\mathrm{Q}[n] \mathrm{s}$, where $\mathrm{n}=5$ to 8 [13-21], some of which are heterometallic capped species involving $\mathrm{K}^{+}$ions [22-24]. Of particular note here are the $\mathrm{Q}[5]$ heterobimetallic complexes $\left.\{[\mathrm{NdKQ}[5] \mathrm{Cl}] \mathrm{Cl}\}\left(\mathrm{H}_{2} \mathrm{O}\right)_{3}\right\} \mathrm{Cl}_{2} \cdot 12.5 \mathrm{H}_{2} \mathrm{O}[22]$ and $\left\{\left[\mathrm{Nd}\left(\mathrm{H}_{2} \mathrm{O}\right)_{3}\right]\left[\left(\mathrm{NO}_{3}\right) @ \mathrm{Q}[5]\right]\left[\mathrm{K}\left(\mathrm{H}_{2} \mathrm{O}\right)\right]\left[\mathrm{Nd}\left(\mathrm{H}_{2} \mathrm{O}\right)_{3}\left(\mathrm{NO}_{3}\right)_{4}\right]\right\} \cdot 2\left(\mathrm{NO}_{3}\right) \cdot 8 \mathrm{H}_{2} \mathrm{O}$ [23]. In the first of these heterobimetallic complexes, where the Q[5] encapsulates a chloride anion, the $\mathrm{Nd}$ centre is nine-coordinate (5 carbonyls at an average distance of $2.531 \AA, 3$ waters at an average distance of $2.516 \AA$ and the internal chloride, whilst the $\mathrm{K}^{+}$is bound by an internal and external chloride as well as 5 oxygen centres of the Q[5]. By contrast, in the second complex, the $\mathrm{K}^{+}$coordinates to ten oxygen atoms ( 5 carbonyls at an average distance of $2.783 \AA, \mathrm{H}_{2} \mathrm{O}$ at $3.257 \AA$ and 4 from two nitrates). Furthermore, in this second structure, the $\mathrm{Nd}$ centre coordinates to nine oxygen atoms (5 carbonyls with distances in the range 2.511-2.570 $\AA, 3 \mathrm{H}_{2} \mathrm{O}$ at an average distance of $2.448 \AA$ and a nitrate). The structures of the two inclusion complexes (herein and the Liu complex) indicate that if the 'external' atoms are part of a larger $\mathrm{Q}[n]$ system, then their coordination to that either $\mathrm{K}$ or $\mathrm{Nd}$ centres of a $\mathrm{Q}[5]$ results in this $\mathrm{Q}[n]$ system being held in a fixed position relative to the inner $\mathrm{Q}[5]$.

The structure of the inclusion complex is retained in solution as evidenced by the ${ }^{1} \mathrm{H} N \mathrm{NR}$ spectrum (see Figure 3), for which the methylene peaks all appear as doublets (i.e., non-equivalent). Whilst the positions of the peaks associated with Q[10] remain relatively unchanged, those of Q[5] tend to be shifted somewhat upfield.

The X-ray photoelectron spectra of $\left\{\mathrm{NdQ}[5] \mathrm{K} @ \mathrm{Q}[10]\left(\mathrm{H}_{2} \mathrm{O}\right)_{4}\right\} \cdot 4 \mathrm{NO}_{3} \cdot 20 \mathrm{H}_{2} \mathrm{O}$ are shown in Figure 4 , and through the elemental mappings (Figure 4a), it is apparent that there is a homogeneous distribution of $\mathrm{K}$ and $\mathrm{Nd}$ in the sample. In addition, in terms of the cations, the obtained crystals contained $50 \% \mathrm{~K}$ and $50 \% \mathrm{Nd}$, suggesting the $\mathrm{X}$-ray photoelectron spectra are consistent with the single crystal structure (Figure $4 b$ ), i.e., 1:1 K:Nd in the crystal. 


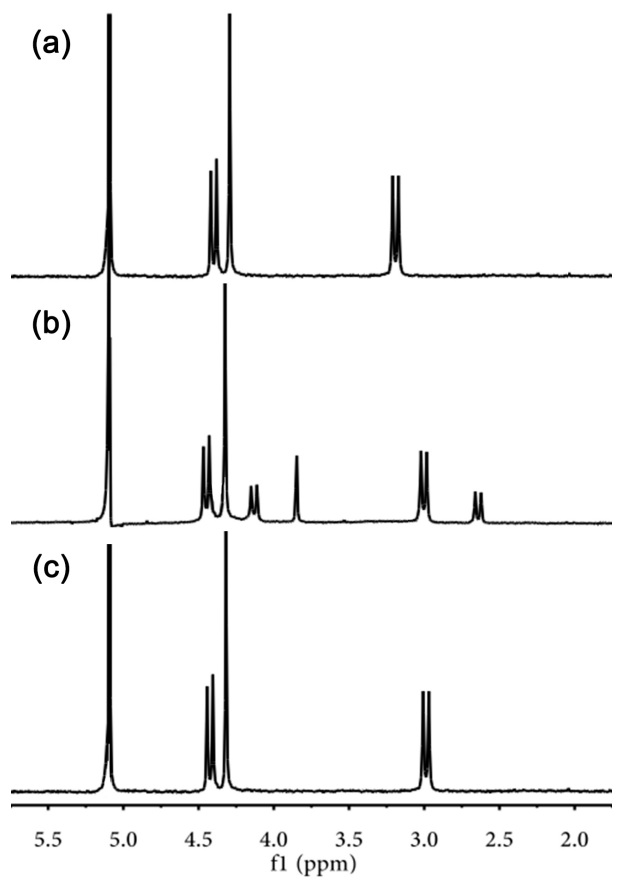

Figure 3. ${ }^{1} \mathrm{H}$ NMR spectra in $4 \mathrm{M} \mathrm{DCl}$ : (a) Q[5]; (b) Q[5]@Q[10]; (c) Q[10].

(a)
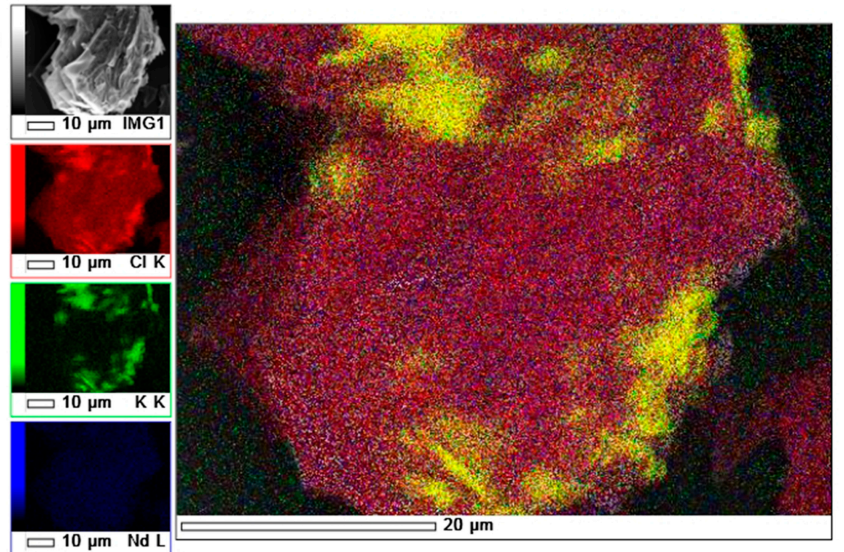

(b)

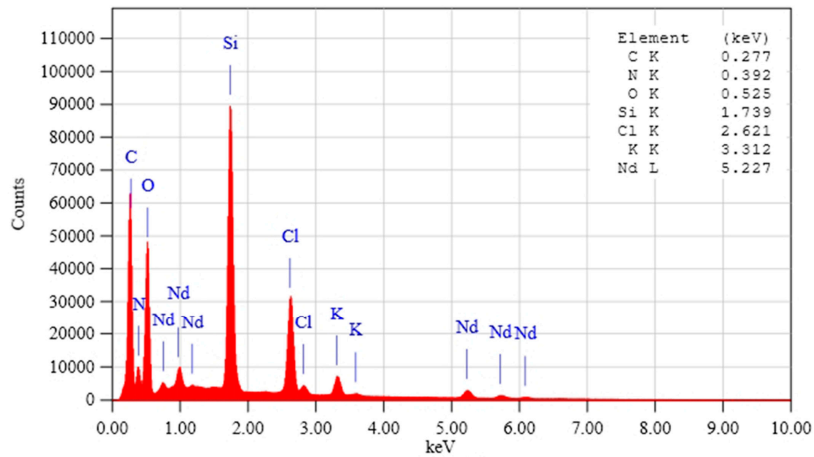

Figure 4. The XPS spectra of the inclusion complex. (a) the X-ray photoelectron spectra of $\{\mathrm{NdQ}[5] \mathrm{K} @ Q[10](\mathrm{H} 2 \mathrm{O}) 4\} \cdot 4 \mathrm{NO}_{3} \cdot 20 \mathrm{H}_{2} \mathrm{O}$ and through the elemental mappings; (b) in terms of the cations, the obtained crystals contained $50 \% \mathrm{~K}$ and $50 \% \mathrm{Nd}$, suggesting the $\mathrm{X}$-ray photoelectron spectra are consistent with the single crystal structure. 


\section{Materials and Methods}

\subsection{General}

All the chemicals were commercially available and used as received without further purification. Glycoluril was synthesized by our laboratory.

\subsection{Measurements}

XPS images were obtained using a JEOL JSM-6700F field-emission scanning electron microscopy (JOEL Ltd, Tokyo, Japan). Elemental analysis was performed on an Elementar Vavio El III (Elementar Analysensysteme GmbH, Frankfurt, Germany).

\subsection{Crystal Structure Determination}

A suitable single crystal $\left(\sim 0.2 \times 0.2 \times 0.1 \mathrm{~mm}^{3}\right)$ was taken up in paraffin oil and mounted on a Bruker SMART Apex II CCD diffractometer (Bruker AXS, Madison, WI, USA) equipped with a graphite monochromator Mo-K $\alpha\left(\lambda=0.71073 \AA, \mu=0.492 \mathrm{~mm}^{-1}\right)$ radiation source operating in the $\omega$-scan mode. Data were corrected for Lorentz and polarization effects using SAINT (Bruker AXS, Madison, WI, USA). The structure was solved by direct methods, and were refined against $\mathrm{F}^{2}$ using the full-matrix least-squares method using SHELXL-2016. [25] All non-hydrogen atoms were refined anisotropically. Carbon-bound hydrogen atoms were introduced at calculated positions, and were treated as riding atoms with an isotropic displacement parameter equal to 1.2 times that of the parent atom. The complexes present are very large and contain over 200 unique non-hydrogen atoms and there are portions of disordered guest molecules. The X-ray scattering drops away very rapidly beyond about $1 \AA$ resolution and data beyond this limit were not employed in the refinement as these are essentially noise. The PLATON Squeeze routine was employed and showed that the structure contained four pockets within the unit cell that contained disordered guest. The total volume of these pockets was $\sim 2280 \AA^{3}$ and this corresponded to an electron count of $4 \times 126 \mathrm{e}$. For charge balancing, an additional disordered nitrate ion is required and the remaining space is occupied by three water molecules [26].

Details of the crystal parameters, data collection conditions, and refinement parameters for the compound are summarized in Table 1. In addition, the crystallographic data for the reported structures were deposited at the Cambridge Crystallographic Data Centre with the following supplementary publication numbers: CCDC-1554311.

\subsection{Synthesis of Complex 1}

A mixture of glycoluril (50 g, $0.35 \mathrm{~mol})$, paraformaldehyde $(26.2 \mathrm{~g}, 0.86 \mathrm{~mol})$, and concentrated $\mathrm{HCl}(100 \mathrm{~mL})$ was stirred at room temperature for $1 \mathrm{~h}$ and then heated at $100{ }^{\circ} \mathrm{C}$ for $6 \mathrm{~h}[7,8]$. The resulting solution was cooled to room temperature and precipitated by pouring into $\mathrm{MeOH}$ $(500 \mathrm{~mL})$ to yield a crude pale yellow solid. The precipitate was extracted three times with $50 \mathrm{~mL}$ of water. The filtered residue (45 g) containing Q[6], Q[8] and Q[5]@Q[10] was dissolved in $6 \mathrm{M} \mathrm{HCl}$ $(300 \mathrm{~mL})$ and amantadines $(7.5 \mathrm{~g})$ were added to induce precipitation $(1.1 \mathrm{~g}$, amantadines-Q[10]). The precipitate was filtered and dried, and refluxed with DMSO $(50 \mathrm{~mL})$ for $30 \mathrm{~min}$. The precipitate was filtered then refluxed with $\mathrm{MeOH}(50 \mathrm{~mL})$ for $30 \mathrm{~min}$, filtered and dried to yield $\sim 1.0 \mathrm{~g}$ of pure $\mathrm{Q}$ [10] [9]. Q[10] (1.66 g, $0.001 \mathrm{~mol})$ and Q[5] (0.83 g, $0.001 \mathrm{~mol})$ was then dissolved in $1 \mathrm{M}$ hydrochloric acid $(100 \mathrm{~mL})$. To this solution was added $\mathrm{Nd}\left(\mathrm{NO}_{3}\right)_{3} \cdot 6 \mathrm{H}_{2} \mathrm{O}(4.38 \mathrm{~g}, 0.01 \mathrm{~mol})$ and potassium chloride $(0.75 \mathrm{~g}, 0.01 \mathrm{mmol})$. The mixture was heated at $80{ }^{\circ} \mathrm{C}$ for $10 \mathrm{~min}$, then left to stand at room temperature in an open beaker. After five weeks, X-ray quality colorless crystals of the title complex were obtained in a yield of $12.1 \%$. Anal. calcd. For $\mathrm{C}_{90} \mathrm{H}_{138} \mathrm{~N}_{64} \mathrm{O}_{66} \mathrm{KNd}(\%)$ : C, 33.59; H, 0.03; N, 27.86, Found: C, 33.41; H, 0.09; N, 27.49. 
Table 1. Crystal data and structure-refinement details for complex 1.

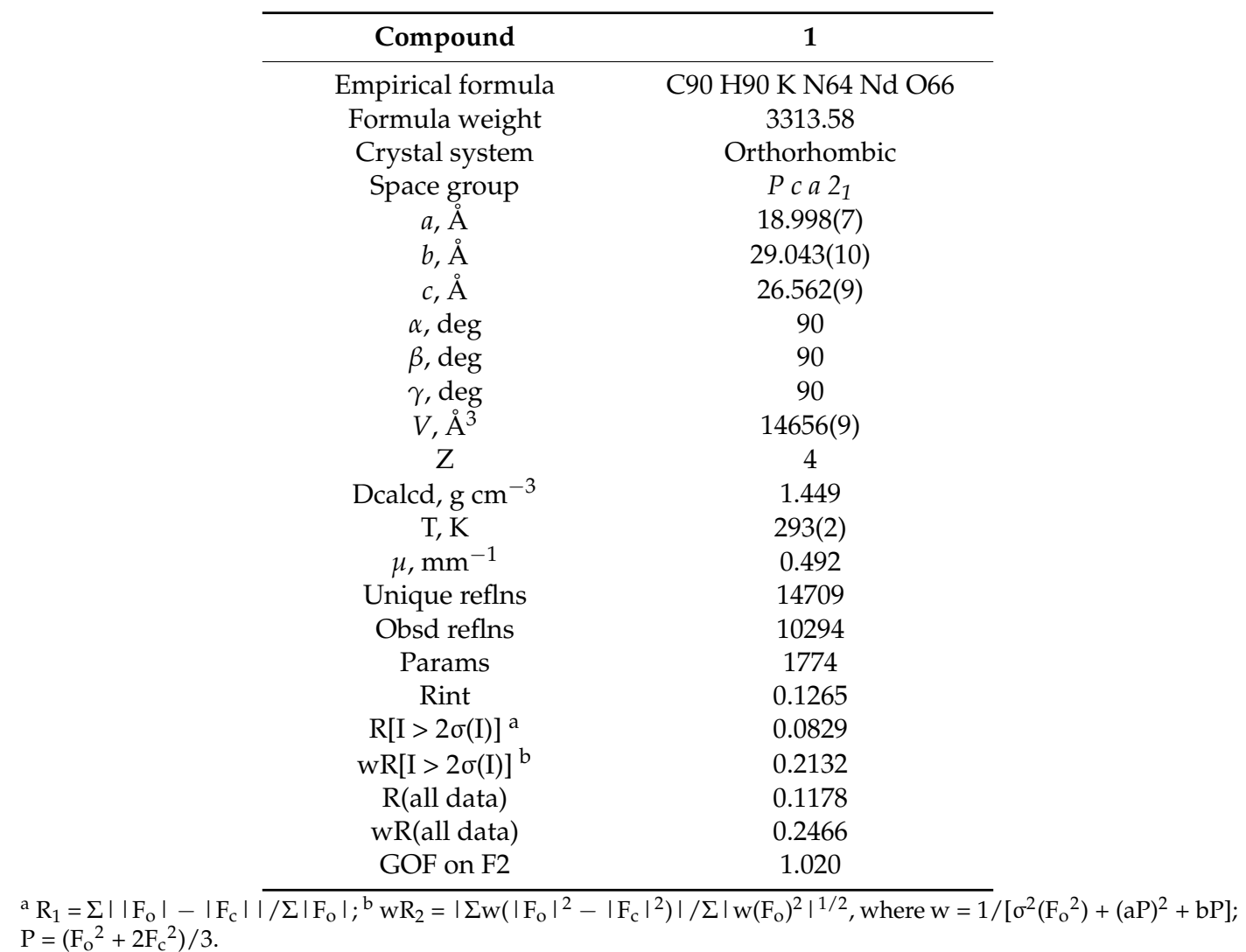

\section{Conclusions}

The inclusion complex $\left\{\mathrm{NdQ}[5] \mathrm{K} @ \mathrm{Q}[10]\left(\mathrm{H}_{2} \mathrm{O}\right)_{4}\right\} \cdot 4 \mathrm{NO}_{3} \cdot 20 \mathrm{H}_{2} \mathrm{O}$ has been isolated from a mixture comprising of $\mathrm{Nd}\left(\mathrm{NO}_{3}\right)_{3} \cdot 6 \mathrm{H}_{2} \mathrm{O}, \mathrm{KCl}, \mathrm{Q}[10]$ and $\mathrm{Q}[5]$ in $\mathrm{HCl}$. A crystal structure determination reveals that the $\mathrm{Q}[5]$ is held firmly within a $\mathrm{Q}[10]$ by coordination of potassium and neodymium ions; the structure is maintained in solution.

Supplementary Materials: The following are available online. Figure S1: Structure of the inclusion complex $\left\{\mathrm{NdQ}[5] \mathrm{K} @ Q[10]\left(\mathrm{H}_{2} \mathrm{O}\right)_{4}\right\} \cdot 4 \mathrm{NO}_{3} \cdot 20 \mathrm{H}_{2} \mathrm{O}$ as viewed from the side ; Figure S2: Dimensions of the $\mathrm{Q}[10]$. The distances are in $\AA$; the inner Q[5] and other atoms have been removed for clarity.

Acknowledgments: We acknowledge the support of National Natural Science Foundation of China (No. 21561007), the Science and Technology Fund of Guizhou Province (No. 2016-1030), and the Innovation Program for High-level Talents of Guizhou Province (No. 2016-5657). CR thanks the EPSRC for the award of a travel grant.

Author Contributions: Li Xia Chen and Hang Cong prepared the complex; Jian Lan Kan performed the XPS experiments; Timothy J. Prior analyzed the X-ray data; Zhu Tao, Xin Xiao and Carl Redshaw wrote the paper.

Conflicts of Interest: The authors declare no conflict of interest.

\section{References}

1. Assaf, K.I.; Nau, W.M. Cucurbit $[n]$ urils: From synthesis to high-affinity binding and catalysis. Chem. Soc. Rev. 2015, 44, 394-418. [CrossRef] [PubMed]

2. Yan, X.; Wang, F.; Zheng, B.; Huang, F. Stimuli-responsive supramolecular polymeric materials. Chem. Soc. Rev. 2012, 41, 6042-6065. [CrossRef] [PubMed] 
3. Ni, X.-L.; Xiao, X.; Cong, H.; Liang, L.-L.; Cheng, K.; Cheng, X.-J.; Ji, N.-N.; Zhu, Q.-J.; Xue, S.-F.; Tao, Z. Cucurbit $[n]$ uril-based coordination chemistry: From simple coordination complexes to novel poly-dimensional coordination polymers. Chem. Soc. Rev. 2013, 42, 9480-9508. [CrossRef] [PubMed]

4. Yu, G.; Jie, K.; Huang, F. Supramolecular amphiphiles based on host-guest molecular recognition motifs. Chem. Rev. 2015, 115, 7240-7303. [CrossRef] [PubMed]

5. Ni, X.-L.; Xue, S.-F.; Tao, Z.; Zhu, Q.-J.; Lindoy, L.F.; Wei, G. Advances in the lanthanide metallosupramolecular chemistry of the cucurbit[n] urils. Coord. Chem. Rev. 2015, 287, 89-113. [CrossRef]

6. Bai, Q.; Zhang, S.; Chen, H.; Sun, T.; Redshaw, C.; Zhang, J.-X.; Ni, X.-L.; Wei, G.; Tao, Z. Alkyl Substituted Cucurbit[6]uril Assisted Competitive Fluorescence Recognition of Lysine and Methionine in Aqueous Solution. Chem. Sel. 2017, 2, 2569-2573. [CrossRef]

7. Day, A.I.; Blanch, R.J.; Arnold, A.P.; Lorenzo, S.; Lewis, G.R.; Dance, I. A Cucurbituril-based Gyroscane: A new Supramolecular Form. Angew. Chem. Int. Ed. 2002, 41, 275-277. [CrossRef]

8. Isaacs, L.; Park, S.-K.; Liu, S.; Young, H.K.; Selvapalam, N.; Kim, Y.; Kim, H.; Zavalij, Y.; Kim, G.-H.; Lee, H.-S.; et al. The Inverted Cucurbit[n]uril family. J. Am. Chem. Soc. 2005, 127, 18000-18001. [CrossRef] [PubMed]

9. Liu, J.-X.; Lin, R.-L.; Long, L.-S.; Huang, R.-B.; Zheng, L.-S. A novel inclusion complex form between Q[10] host and Q[5] guest stabilized by potassium ion coordination. Inorg. Chem. Commun. 2008, 11, 1085-1087. [CrossRef]

10. Day, A.I.; Arnold, A.P.; Blanch, R.J. Cucurbiturils and Methods for Binding Gases and Volatiles Using Cucurbiturils. U.S. Patent US006869466B2, 22 March 2005.

11. Kim, J.; Jung, I.-S.; Kim, S.-Y.; Lee, E.; Kang, J.-K.; Sakamoto, S.; Yamaguchi, K.; Kim, K. New Cucurituril Homologues: Syntheses, Isolation, Characterization, and X-ray Crystal Structures of Cucurit $[n]$ uril ( $\mathrm{n}=5,7$ and 8). J. Am. Chem. Soc. 2000, 122, 540-541. [CrossRef]

12. Liu, S.; Yang, X.; Gong, W. Method for Preparing High-Purity Cucurbit[10]uril. CN Patent CN104557951, 19 April 2015.

13. Mainicheva, E.A.; Tripolskaya, A.A.; Gerasko, O.A.; Naumov, D.Y.; Fedin, V.P. Synthesis and crystal structures of $\mathrm{Pr}^{\mathrm{III}}$ and $\mathrm{Nd}^{\mathrm{III}}$ complexes with the macrocyclic cavitand cucurbit[6]uril. Russ. Chem. Bull. 2006, 55, 1566-1573. [CrossRef]

14. Thuéry, P. Second-sphere tethering of rare-earth ions to cucurbit[6]uril by iminodiacetic acid involving carboxylic group encapsulation. Inorg. Chem. 2010, 49, 9078-9085. [CrossRef] [PubMed]

15. Thuéry, P. L-Cysteine as a chiral linker in lanthanide-cucurbit[6]uril one-dimensional assemblies. Inorg. Chem. 2011, 50, 10558-10560. [CrossRef] [PubMed]

16. Thuéry, P. Lanthanide ion complexes with 2-, 3- or 4-sulfobenzoate and cucurbit[6]uril. Cryst. Growth Des. 2012, 12, 1632-1640. [CrossRef]

17. Liang, L.-L.; Ni, X.-L.; Zhao, Y.; Chen, K.; Xiao, X.; Zhang, Y.-Q.; Redshaw, C.; Zhu, Q.-J.; Xue, S.-F.; Tao, Z. Construction of cucurbit[7]uril based tubular nanochannels incorporating associated $\left[\mathrm{CdCl}_{4}\right]^{2-}$ and lanthanide ions. Inorg. Chem. 2013, 52, 1909-1915. [CrossRef] [PubMed]

18. Zhao, Y.; Liang, L.-L.; Chen, K.; Zhang, T.; Xiao, X.; Zhang, Y.-Q.; Tao, Z.; Xue, S.-F.; Zhu, Q.-J. Inorganic anion-aided coordination of lanthanide metal ions to cucurbituril and supramolecular self-assembly: Potential applications in the separation of light lanthanides. CrystEngComm 2013, 15, 7987-7998. [CrossRef]

19. Cheng, X.-J.; Ji, N.-N.; Zhao, Y.; Liang, L.-L.; Xiao, X.; Zhang, Y.-Q.; Xue, S.-F.; Zhu, Q.-J.; Tao, Z. $\left[\mathrm{CdCl}_{4}\right]^{2-}$ anion-induced coordination of $\mathrm{Ln}^{3+}$ to cucurbit[8]uril and the formation of supramolecular self-assemblies: Potential application in isolation of light lanthanides. CrystEngComm 2014, 16, 144-147. [CrossRef]

20. Zhang, D.-Q.; Zhang, Y.-Q.; Xue, S.-F.; Tao, Z.; Xiao, X.; Zhu, Q.-J. Coordination of lanthanides in the inverted cucurbituril supramolecular assemblies formed in the presence of tetrachloride zincate anion: Potential applications for isolation of lighter lanthanides. Polyhedron 2015, 99, 147-155. [CrossRef]

21. Yang, B.; Gao, Z.-Z.; Lu, J.-H.; Zhu, Q.-J.; Xue, S.-F.; Tao, Z.; Prior, T.J.; Redshaw, C.; Wei, G.; Xiao, X. Interaction of a symmetrical $\alpha, \alpha^{\prime}, \delta, \delta^{\prime}$-tetramethylcucurbit[6]uril with $\mathrm{Ln}^{3+}$ : Potential applications for isolation of lanthanides. CrystEngComm 2016, 18, 5028-5035. [CrossRef]

22. Liu, J.; Gu, Y.; Lin, R.; Yao, W.; Liu, X.; Zhu, J. Anion encapsulation by Ln(III)/K(I) heterobismetal-capped cucurbit[5]uril. Supramol. Chem. 2010, 22, 130-134. [CrossRef]

23. Liang, L.-L.; Chen, K.; Feng, X.; Zhang, Y.-Q.; Zhu, Q.-J.; Xue, S.-F.; Tao, Z. Three cucurbit[5]uril-based heterometallic complexes. J. Mol. Struct. 2011, 1006, 87-90. [CrossRef] 
24. Han, B.-X.; Wang, C.-Z.; Chen, K.; Xiao, X.; Tao, Z.; Xue, S.-F.; Zhang, Y.-Q.; Zhu, Q.-J. Coordination and supramolecular assemblies of $\mathrm{K}^{+} / \mathrm{Ln}^{3+}$ to perhydroxycucurbit[5] uril in the presence of $\left[\mathrm{PMo}_{12} \mathrm{O}_{40}\right]^{3-}$ : Potential application in isolation of light lanthanides. CrystEngComm 2014, 16, 1615-1619. [CrossRef]

25. Sheldrick, G.M. Crystal structure refinement with SHELXL. Acta Cryst. 2015, C71, 3-8.

26. Sheldrick, G.M. A short history of SHELX. Acta Cryst. Sect. A 2008, 64, 112-122. [CrossRef] [PubMed]

Sample Availability: Samples of the compound are not available from the authors.

(C) 2017 by the authors. Licensee MDPI, Basel, Switzerland. This article is an open access article distributed under the terms and conditions of the Creative Commons Attribution (CC BY) license (http://creativecommons.org/licenses/by/4.0/). 